\title{
Standardization of inoculation technique to identify the sources of resistance against stem and pod rot of groundnut
}

Poornima*1 and Gururaj Sunkad ${ }^{2}$

${ }^{1}$ Department of Plant Pathology, AICRP (Sunflower), MARS, Raichur (Karnataka) India

${ }^{2}$ Department of Plant Pathology, University of Agricultural Sciences, Raichur (Karnataka) India

\section{ARITCLE INFO}

Received : 27.01 .2020

Revised : 27.02 .2020

Accepted : 12.03 .2020

\section{KEY WORDS :}

Groundnut, Stem, Pod rot, S.rolfsii
*Corresponding author:

Email : poornimaagri@gmail.com

\begin{abstract}
A technique was standardized to screen for resistance to stem rot (Sclerotium rolfsii Sacc.) in groundnut (Arachis hypogaea L.). A total of seven different inoculation techniques were screened by using susceptible genotype TMV-2. The techniques involved inoculation of 10 day old groundnut plants raised in pots by spreading mycelial propagules of $S$. rolfsii grown on sorghum grain medium (SGM) on soil surface, Inoculum spread on the soil surface and covered with groundnut leaf debris, Inoculum placed around the collar region, Inoculum placed around the collar region and covered with groundnut leaf debris, Inoculum mixed in the soil, Inoculum mixed in the soil and covered with groundnut leaf debris, Agar disc method. Among these techniques inoculum spread on the soil surface and covered with groundnut leaf debris was found to be most efficient in getting highest per cent incidence of stem rot $(84.86 \%)$ and pod $\operatorname{rot}(70.48 \%)$.
\end{abstract}

How to view point the article : Poornima and Sunkad, Gururaj (2020). Standardization of inoculation technique to identify the sources of resistance against stem and pod rot of groundnut. Internat. J. Plant Protec., 13(1) : 58-61, DOI : 10.15740/HAS/IJPP/13.1/58-61, Copyright@ 2020: Hind Agri-Horticultural Society. 